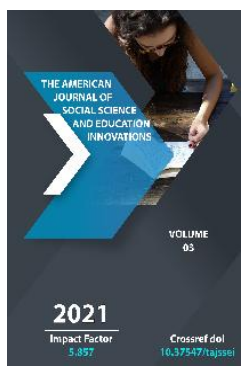

\title{
Women's Sports And Reproductive Health Issues
}

\section{Ali Eshmyminovich Tursaotov Teacher Of Physical Education Department Of Uzbek Language And Literature Of The Tashkent Institute Of Architecture And Construction, Uzbekistan}

Journal Website:

http://theamericanjour

nals.com/index.php/taj

ssei

Copyright: Original content from this work may be used under the terms of the creative commons attributes - $1: \ldots . . .-$.

\section{ABSTRACT}

The paper considers the process of physical training of female athletes. Recommendations are given for the formation of the load within reasonable limits, which differ from the intensive training regime.

\section{KEYWORDS}

Women's sports, reproductive health, fertility, infertility.

\section{INTRODUCTION}

Sports, intensive training, excessive physical and mental stress on the body of athletes, as well as the use of various chemical, including hormonal drugs to strengthen the body and increase its performance, often lead to changes in their reproductive system, in the form of reduced fertility and, often, infertility [1.5].The World Health Organization (WHO), defining the concept of "reproductive health", considers it not only as the absence of diseases and pathological conditions of the 
male and female genital and reproductive organs, but

also explains it as "...the absence of pathology and disorders of reproductive functions in men and women". Following this concept, WHO also defines reproductive health as "the physical, mental and social well-being of both partners, both male and female" $[1,2,4]$.

Fertility is one of the oldest components of the reproductive system of men and women, which determines the possibility of conceiving a child. The medical and biological term "fertility" comes from Lat. "fertilis" — "fertile, fertile". This is the ability of a sexually mature organism to produce viable offspring $[2,3]$. Synonyms of the concept of "fertility" "fertility", "reproductivity". i.e.," fertility " of a person, as an evolutionarily developed ability of organisms to bring viable offspring.

Fertility is a manifestation of the preservation of ovulatory function in women and generative function in men. Lifestyle choices, including sports or intensive training, as well as fitness, dance, or other sports and training activities, can have a particularly significant impact on female fertility.

As for the issue of infertility, the term "infertility", as a preliminary diagnosis, is used in relation to a married couple or partners, in the absence of pregnancy for a year, or rather 12 OMTs (ovarian-menstrual cycles) after the start of regular, unprotected sex, i.e. without the use of any methods or means of contraception. According to published research data, in $60 \%$ of cases, pregnancy occurs between 3 and 7 months of child planning. $10 \%$ of women become pregnant after 10-12 months.
Age also plays an important role in female fertility. In women, unlike men, the chances of getting pregnant are directly related to their age. Women are most fertile around the age of twenty, and their fertility most often begins to decline when they reach the age of thirty or more. In obstetric and gynecological practice, it is considered that women after 30 years are conditionally considered "old-born" or "old first-born". And this is due precisely to possible problems with the state of her physical and mental health and, undoubtedly, with their fertility $[2,3,4]$.

It is no secret that the majority of female athletes, especially representatives of professional "big sports", postpone the creation of a family, and especially the birth of a child, for "later", sometimes until the end of their professional career $[1,2,4]$. This is especially true for female athletes, whose best "reproductive age" goes to the training and competition period, when she is not up to family and the birth of children.

Postponing pregnancy can reduce the likelihood that a woman who has been in an intensive training and competition mode for many years will be able to conceive a child at all. And there are a lot of such examples, both in domestic and foreign professional sports. The fate of these women, unfortunately, is the long-term treatment of infertility, methods of artificial insemination, surrogacy or adoption of children.

If an athlete has a normal BMI and plans to become pregnant in the near future, then she should consider limiting aerobic exercise to seven hours a week. But in the event that an athlete has problems with weight, especially when her body weight is approaching a critical 
level that is insufficient to preserve the most important reproductive component, such as menstruation, it is necessary to urgently consult a gynecologist and endocrinologist, strictly control her weight and the amount of adipose tissue, as well as undergo a number of special studies of the state of her reproductive system. With a sports doctor, based on the results of the survey, you will need to coordinate your training and competition cycle and individually determine how much aerobic exercise will help you get yourself in order.

Therefore, the process of physical training should be formed within reasonable limits, different from the intensive training regime. Otherwise, the consumption of all the energy available in the system will lead to such a depletion of its reserves, in which the energy charge is simply not enough - neither for ovulation, nor for fertilization, and even more so for pregnancy.

\section{CONCLUSIONS}

1. If a female athlete has any problems with reproductive health, and even more so she is thinking about pregnancy, and she is concerned about the impact on the fertility of her lifestyle, she should immediately consult with her coach and sports doctor, review her loads, training regimen, adjust $\mathrm{BMI}$ and consult a gynecologist-endocrinologist. It will be able to help you with methods and ways that will help improve fertility and increase the chances of getting pregnant.

2. Reasonably selected loads, balanced nutrition, exercise and rest, balance and competent construction of the training and competition cycle of the athlete will help her to fully experience the charms of female happiness and experience the joy of motherhood.

\section{REFERENCES}

1. Литисевич, Л.В. Репродуктивное здоровье актуальная проблема в современном спорте высших достижений/ Журнал Российской ассоциации по спортивной медицине и реабилитации больных и инвалидов. 2005.- №3. - С.27.

2. Ниаури, А.А. Репродуктивное здоровье женщины в спорте. Методическое пособие./Д.А Ниаури, Т.А Евдокимова, Е.И Сазыкина, М.Ю. Курганова; под ред. Айламазяна Э. К..-2003, 28 c.

3. Сазыкина, Е.И. Состояние репродуктивного здоровья женщинспортсменок /Е.И. Сазыкина, Э.К. Айламазян, Д.А. Ниаури, Т.А.Евдокимова //Журн. акушерства и жен. болезней. 2001. - Т.50. №2. С. 33-37

4. Юрчук, О.А. Репродуктивное здоровье спортсменок./ О.А. Юрчук, В.И. Циркин, С.В. Хлыбова // Ремедиум Поволжье. Охрана здоровья матери и ребенка.-2006. С. 11-113.

5. Bidzan Mariola, Niepłodność w ujęciu bio-psycho-społecznym, Oficyna Wydawnicza "Impuls", Kraków 2010.

6. Atxamdjanovna, F. K. (2020, December). Effectiveness of physical culture education effects of adolescents on scientific thinking in growth location of effective information. In Конференции. 